\title{
Activity and isoenzyme composition of peroxidase in the vegetative organs of Japanese quince under steppe zone conditions
}

Yuriy Prisedsky ${ }^{1}$,

Anatoliy Kabar²,

Yuriy Lykholat ${ }^{2}$,

Nadezhda Martynova²,

Larysa Shupranova ${ }^{2}$

${ }^{1}$ Vasyl Stus Donetsk

National University,

600-richya St., 21,

21021 Vinnitsa, Ukraine

${ }^{2}$ Oles Honchar Dnipropetrovsk

National University, Haharina Ave. 72,

49000 Dnipro, Ukraine
Parameters of peroxidase complex are indicators of the adaptable processes which are taking place in plants under the environment influence. In this work the general activity dynamics and peroxidase isoenzyme composition in vegetative organs of Japanese quince (Chaenomeles Lindl.) were studied. The four species introduced in a steppe zone of Ukraine were researched: Ch. japonica (Thunb.) Lindl., Ch. speciosa (Sweet) Nak., Ch. cathayensis (Hemsl.) Schneid., Ch. $\times$ superba (Frahm) Red.). It was determined that the enzyme activity of these species possesses specific features subject to the phases of seasonal development and in response to the action of the hydrothermal stress. The highest enzyme activity in the period of intensive growth and flowering, with a subsequent sharp drop towards the middle of summer and further smoother decrease during the phase of physiological rest were observed in the leaves of Ch. speciosa and Ch. cathayensis. A higher peroxidase activity was a characteristic of Ch. japonica and Ch. $\times$ superba in the middle of the vegetative period, which can be considered a display of adaptation processes in the conditions of an unfavourable hydrothermal regime. The dynamics of changes in the quantitative composition of isoperoxidases was similar to the dynamics of enzyme activity. As a result of the generalization of the obtained data it is possible to consider that Ch. japonica and Ch. $\times$ superba are the steadiest in the conditions of the region.

Keywords: Japanese quince, introduction, peroxidase, adaptation, stability

\section{INTRODUCTION}

Introduction of nonconventional fruit crops represents a considerable interest for the preservation of the biological variety and expansion of

* Corresponding author. E-mail: tolos@i.ua the spectrum of valuable agricultural plants (Convention, 2012; Klimenko, 2007; Yermakov, 1999; Klimenko et al., 2010; Mezhenskij, 2005; Sorokopudov et al., 2013). This group includes Japanese quince (Chaenomeles Lindl.). Its fruits are rich in pectins, organic acids, vitamins $C, B_{1}, B_{2}, P$, and macroelements such as phosphorus, potassium and calcium (Petrova, 1986; Yang et al., 2009). 
Japanese quince is a very useful product for a healthy diet: it does not contain fats, sodium, or cholesterol, and is rich in organic fibres and copper (Song et al., 2007).

Natural habitats of Japanese quince are located in the mountain areas of South-East (Ch. cathayensis) and East (Ch. japonica, Ch. speciosa) Asia. Ch. $\times$ superba is a product of natural hybridization of Ch. japonica and Ch. speciosa. Monsoonal circulation, which creates sharply expressed distinction between damp warm and dry cold seasons, is the basic feature of the climate formation in these regions. Dry seasons are winter and spring and damp seasons are summer and autumn. At the same time, climatic conditions of the Ukraine steppe zone are characterized by insufficient water delivery and high air temperatures during summer and early autumn. It is a powerful limiting factor for plant introduction.

The process of plant adaptation to unfavourable conditions is accompanied by the occurrence of specific and nonspecific reactions at all levels of the structural organization (Bobrova et al., 2010; Mitteler, 2002). Their display is controlled by simultaneous action of numerous regulatory mechanisms, one of which is dynamics of enzyme activity of the antioxidant system (Lykholat et al., 2015; Rossihina et al., 2011; Verslues et al., 2006; Kolupaev, Karpec, 2010; Kucherenko, Kapustyan, 2004). The activity and isoenzyme composition of peroxidase represents a special interest (Biryuk, 2002; Chaves, Oliveira, 2004). It is a nonspecific universal enzyme with a wide spectrum of action. It provides an optimum course of oxidation-reduction processes, takes part in breathing processes and metabolism of proteins and along with other enzymes of antioxidant protection neutralizes active forms of oxygen and provides complex protection of biopolymers (Gulen, 2004; Chirkova, 2002).

In the conditions of a droughty climate targeted researches into plant metabolism under the influence of hydrothermal stress get a special urgency (Almeselmani et al., 2006; Minnibaeva, 2003). It is known that the activity of enzymes increases in the steadiest species of plants under adverse conditions. It can occur at the expense of the strengthening of the activity of separate components of the system or of the whole complex (Sadvakasova, Kunaeva, 1987; Haluskova et al., 2009).

Thus, ongoing studies of the peroxidase complex in the vegetative organs of Japanese quince will allow estimating the level of their stability in the conditions of introduction.

\section{MATERIALS AND METHODS}

\section{Plant material}

Four species of Japanese quince (Ch. japonica, Ch. speciosa, Ch. cathayensis and Ch. $\times$ super$b a$ ), introduced in the Botanical Garden of Oles Gonchar Dnipropetrovsk National University were the objects of research. The parameters of the peroxidase complex were determined in plant shoots and leaves. Sampling was made during the vegetative season from same-age plants within one experimental site. The activity of peroxidase in the samples was determined according to Boyarkin method (Vinnichenko et al., 2014). The definition of the isoenzyme composition of peroxidase was carried out by method of analytical isoelectric focusing (IEF) in polyacrylamide gel (PAAG) in $\mathrm{pH}$ 3.5-7.0 range (Rygetti, 1986; Shupranova et al., 2011).

\section{Statistical Analysis}

Classical methods of statistical processing were applied to the estimation of reliability of the obtained results by means of computer software package Excel and StatGraphics Plus. The significance value $-P<0.05$.

\section{RESULTS AND DISCUSSION}

Only under the influence of stressful factors it is possible to reveal the display of the mechanisms of adaptation and the potential of plant stability. The impact of the Ukraine steppe zone environment can be considered one of these factors (Fig. 1).

The water deficiency caused by frequent droughts and the heat of air throughout almost entire vegetative period are capable to lead to a disbalance in the functioning of a vegetative 


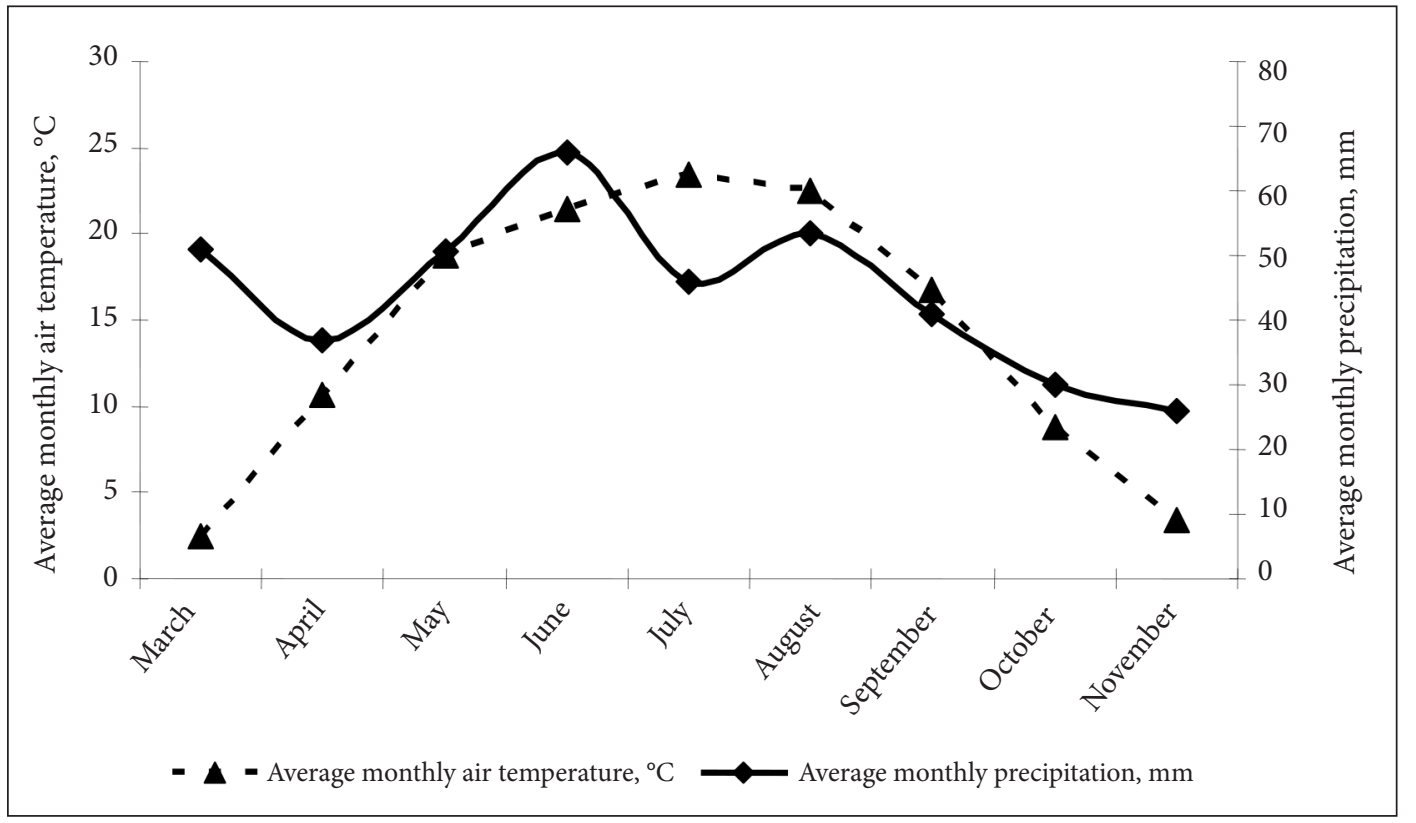

Fig. 1. Average monthly air temperature and precipitation in Dnipro city, 2011-2015

organism. The activity of peroxidase is an indicator of the plant reaction to environmental factors. The stages of ontogenesis also influence the said indicator (Andreeva, 1988).

All studied species of Japanese quince have a similar type of seasonal development. The spring expansion of buds begins in April, flowering comes at the end of April and proceeds till the end of May. The period of maturing of fruits continues from the last decade of September to the end of October. Leaf fall begins in October and only Ch. cathayensis continues to vegetate to the first frosts (November).

It was revealed that the highest activity of peroxidase in vegetative organs occurs in Ch. speciosa and Ch. cathayensis in May, in the phase of active growth and flowering (Fig. 2).

During this period the activity of the enzyme was average in Ch. japonica and Ch. $\times$ superba. Various levels of activity of enzyme system can be special individual indicators in various species of Japanese quince. It is necessary to notice that especially high values of the activity of enzyme are inherent in Ch. speciosa and Ch. cathayensis, which have been introduced in the conditions of the region rather recently.

The significant decrease in peroxidase activity in Ch. speciosa (three times) and Ch. cathayensis (four times) was observed in the middle of vegetation (the phase of secondary growth). As a rule, the given period coincides with the most adverse hydrothermal regime that probably brings about a sharp disbalance in enzyme functioning. The small increase in the activity of enzyme (by $3 \%$ and $27 \%$, respectively) was observed at the same time in two other species of Japanese quince - Ch. japonica and Ch. $\times$ superba, which points to the progress of adaptive processes.

Peroxidase activity reaches its minimum values in the phase of physiological rest in all studied species of Japanese quince. The decrease in the activity of the enzyme by the end of vegetation is explained by the reduction of intensity of the metabolic processes in a vegetative organism and preparation for the winter rest.

The results of the study will be co-ordinated with the data of other works on the introduction of wood and shrub plants (PetrovskayaBaranova, 1983; Zaytceva, Dolgova, 2011).

The changes in peroxidase activity can occur under the influence of adverse factors both at the expense of the already available isoenzymes and of the synthesis of new isoforms. Isoenzymes expand adaptive possibilities of an organism and raise its ecological plasticity due to their various physical and chemical properties 


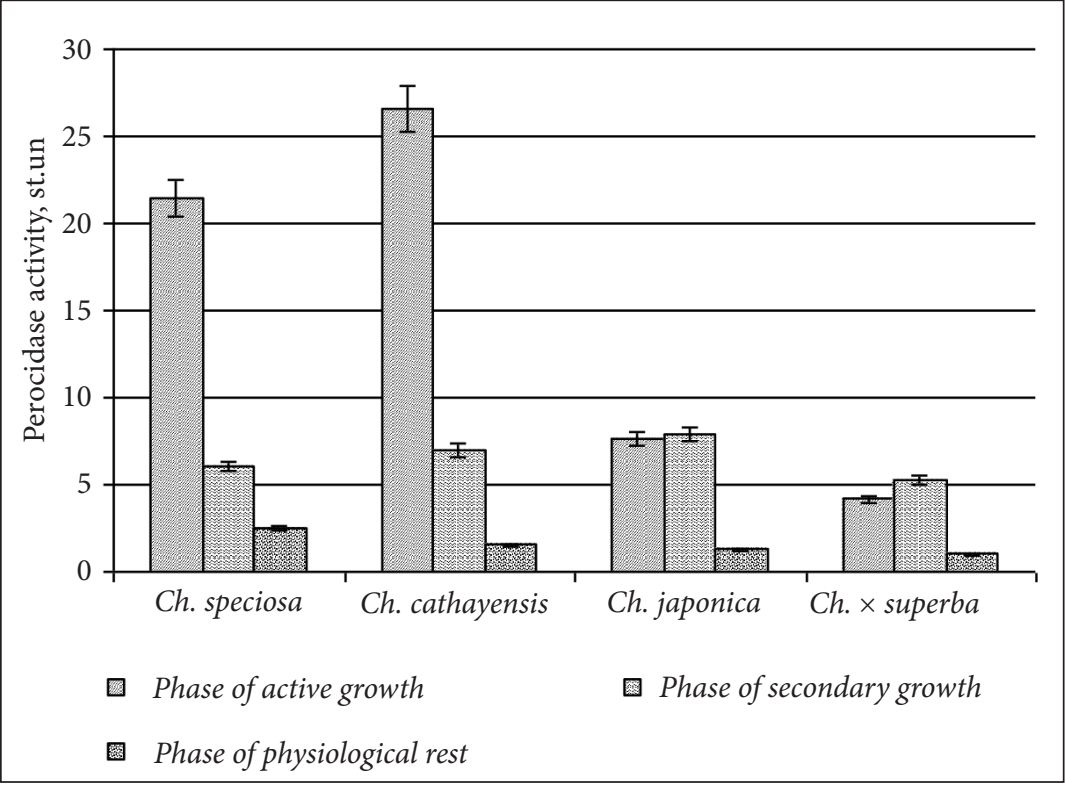

Fig. 2. Activity of peroxidase in the vegetative organs of Japanese quince throughout the vegetative period
(Lagrimini et al., 1990; Popkova, 2006). Different species of Japanese quinces have shown the specificity of the spectra of isoenzymes of peroxidase (Fig. 3).

The presence of six isoperoxidases in the $\mathrm{pH}$ range from 3.80 to 4.70 for the species of $C h$. japonica in the active period of growth and flowering is registered (Table 1). The maximum activity of peroxidase is concentrated in the zone with the value of the isoelectric point (pI) being 4.30 .
The presence of eight components for Ch. speciosa and Ch. Cathaensis is noted, in the range of $\mathrm{pH}$ from 3.80 to 5.20. It was observed that the maximum activity of peroxidase was in the zone with pI 4.30, and the minimum activity in zones with pI 5.05 and 5.20. It is necessary to note that there are only traces of components with the value pI 3.8 in the vegetative material of Ch. cathaensis. For Ch. $\times$ superb, seven isoforms with the $\mathrm{pH}$ range from

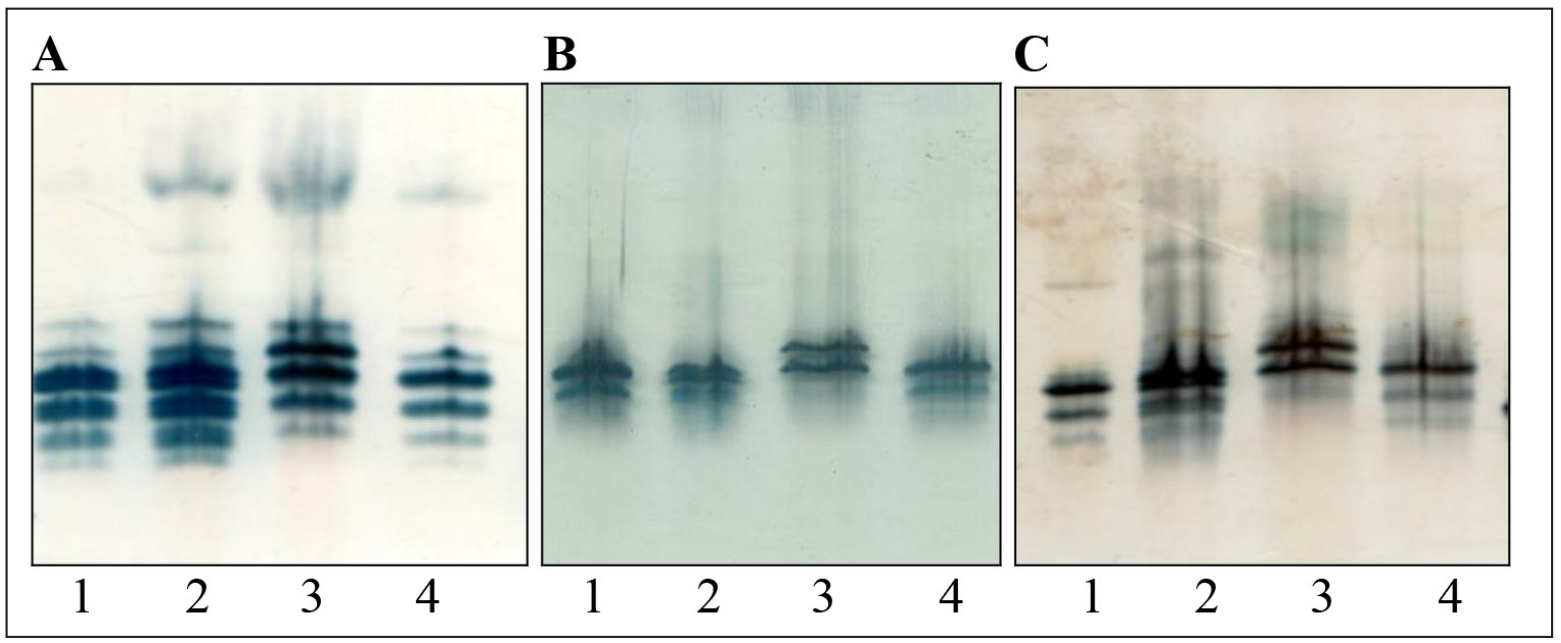

Fig. 3. IEF-PAGE analysis of the peroxidase system of the vegetative organs of Japanese quince during different periods of vegetation ( $\mathrm{A}$ - the phase of active growth and flowering, $\mathrm{B}$ - the phase of secondary growth and ripening of sprouts, $\mathrm{C}$ - the phase of physiological rest): 1 - Chaenomeles japonica; 2 - Chaenomeles speciosa; 3 - Chaenomeles cathayensis; 4 - Chaenomeles $\times$ superba 
Table 1. Values of isoelectric points of peroxidase isoenzymes in the vegetative organs of various species of Chaenomeles genus (the phase of active growth and flowering)

\begin{tabular}{c|c|c|c|c}
\hline \multirow{2}{*}{ Values of pI } & \multicolumn{5}{c}{ Species of Chaenomeles Lindl. } \\
\cline { 2 - 5 } & Ch. japonica & Ch. speciosa & Ch. cathaensis & Ch. $\times$ superba \\
\hline 3.80 & + & + & tr. & tr. \\
\hline 3.90 & ++ & ++ & + & + \\
\hline 4.05 & +++ & +++ & - & + \\
\hline 4.10 & - & - & ++ & +++ \\
\hline 4.30 & ++++ & ++++ & +++ & - \\
\hline 4.48 & + & + & - & + \\
\hline 4.50 & - & - & ++ & tr. \\
\hline 4.70 & + & + & - & tr. \\
\hline 4.75 & - & - & tr. & - \\
\hline 5.05 & - & tr. & tr. & + \\
\hline 5.20 & - & tr.
\end{tabular}

Note: intensity of isoperoxidases colouring: tr. - traces; + - very poor; ++ - poor; +++ - strong; ++++ - very strong.

3.80 to 5.05 were determined, one of which is also a characteristic of Ch. speciosa. Absence of components with values of pI 4.05, 4.48, and 4.70 and an occurrence of the isoform with the value of pI 4.50 were established.

It was revealed that the reduction in the quantity of isoforms for all investigated species was in the middle of vegetation. Absence of components with value of $\mathrm{pI} 5.10$ in the vegetative material of Ch. cathaensis and Ch. $\times$ superba, and with the value of pI 5.15in Ch. japonica and Ch. speciosa, as well as an occurrence of the isoform with the value of $\mathrm{pI} 5.21$ at Ch. cathaensis were determined (Table 2). The maximum activity of peroxidase was established in the zone with the value of pI 5.20 for all investigated species. It is necessary to point out that $\mathrm{pH}$ is displaced to less sour isoperoxidases in an unfavourable hydrothermal regime. Changes in the peroxidase isoenzyme composition were also noticed in September.

The majority of the components remain as traces. It corresponds to the data on the general decrease in the peroxidase activity during this period. Thus the maximum enzyme activity is observed in the zone with the value of pI 4.80 for all investigated species, except Ch. cathaensis in which a high activity of peroxidase in zones with pI 4.90 and 4.95 was shown (Table 3).

Isoforms with the value of pI 4.90 and 5.23 were inherent only in this species. Isoenzymes

Table 2. Values of the isoelectric points of peroxidase isoenzymes in the vegetative organs of various species of genus Chaenomeles (the phase of secondary growth)

\begin{tabular}{c|ccccc}
\hline \multirow{2}{*}{ Values of pI } & \multicolumn{5}{c}{ Species of Chaenomeles Lindl. } \\
\cline { 2 - 5 } & Ch. japonica & Ch. speciosa & Ch. cathaensis & Ch. $\times$ superba \\
\hline 5.05 & - & tr. & - & - \\
\hline 5.10 & ++ & + & - & - \\
\hline 5.15 & - & - & tr. & ++ \\
\hline 5.20 & ++++ & ++++ & +++ & +++ \\
\hline 5.21 & - & - & +++ & -
\end{tabular}

For the intensity of isoperoxidases colouring, see Table 1. 
Table 3. Values of the isoelectric points of peroxidase isoenzymes in the vegetative organs of various species of genus Chaenomeles (the phase of physiological rest)

\begin{tabular}{|c|c|c|c|c|}
\hline \multirow{2}{*}{ Values of pI } & \multicolumn{4}{|c|}{ Species of Chaenomeles Lindl. } \\
\hline & Ch. japonica & Ch. speciosa & Ch. cathaensis & Ch. $\times$ superba \\
\hline 4.27 & tr. & tr. & - & - \\
\hline 4.50 & tr. & tr. & - & tr. \\
\hline 4.60 & + & + & - & - \\
\hline 4.75 & - & - & - & + \\
\hline 4.80 & ++ & +++ & tr. & ++ \\
\hline 4.90 & - & - & +++ & - \\
\hline 4.95 & - & - & +++ & tr. \\
\hline 5.00 & - & tr. & - & - \\
\hline 5.10 & tr. & - & - & - \\
\hline 5.18 & - & tr. & tr. & - \\
\hline 5.23 & - & - & $\operatorname{tr}$ & - \\
\hline
\end{tabular}

For the intensity of isoperoxidases colouring, see Table 1.

with value of pI 4.95 were found in small quantities in the leaves of Ch. $\times$ superba. In the vegetative material of Ch. japonica and Ch. speciosa components in the $\mathrm{pH}$ range of 4.27 to 4.60 were stable. In the enzyme spectrum of the vegetative material of Ch. speciosa the isoform with the value of $\mathrm{pI} 5.00$ which is absent in other species of Japanese quince, was determined.

\section{CONCLUSIONS}

The conducted research revealed that the presence of a considerable quantity of peroxidase isoforms in the phase of active growth and flowering points to the progress in this period of intensive metabolic processes in the vegetative organs of Japanese quince. However, high activity of the enzyme in Ch. speciosa and Ch. cathaensis can indicate not only a specific difference, but also too big expenses of energy which is spent by plants for homeostasis maintenance.

An unfavourable hydrothermal regime leads to a sharp disbalance in the functioning of peroxidase of these species. At the same time, despite the reduction of isoenzyme spectrum in Ch. japonica and Ch. $\times$ superba, the general activity of peroxidase rises a little, that points to the adaptation of these plants to stressful factors.
Thus, in the conditions of the steppe zone of Ukraine it is possible to consider that $C h$. japonica and Ch. $\times$ superba are the steadiest species and Ch. speciosa and Ch. cathaensis are the species of average stability. It is necessary to apply additional agrotechnical methods for their successful cultivation in this region.

Received 13 January 2017 Accepted 24 May 2017

\section{References}

1. Almeselmani M, Deshmukh PS, Sairam RK, Kushwaha SR, Singh TP. Protective role of antioxidant enzymes under high temperature stress. Plant Sci. 2006; 171(3): 382-8.

2. Andreeva VA. Peroxidase enzyme. Participation in the plant protective mechanism. Moscow: Nauka; 1988.

3. Biryuk EN. Peroxidase: its functions and a role in plant organisms. Orcharding. 2002; 14 : $151-80$.

4. Bobrova OM, Lykholat YV, Grygoruk IP, Serga AI, Yavorovskii PP. The activity of antioxidant enzymes in leaves of different plant 
species of barberry (Berberis L.) for heavy metals. Naukovy dopovidi NUBIP. Vol. 5(10): http:// www.nbuv.gov.ua/e-journals/Nd20101/10bomahm.pdf. 2010. 1-10.

5. Chaves MM, Oliveira MM. Mechanisms Underlying plant resilience to water deficits: prospects for water-saving agriculture. J Exp Bot. 2004; 55: 2365-84.

6. Chirkova TV. Physiological fundamentals of plant hardness. S-Pet University; 2002.

7. Convention on Biological Diversity (CBD) (2012). Global Strategy for Plant Conservation: 2011-2020. BGCI: Richmond, UK.

8. Gulen H. Effect of heat stress on peroxidase activity and total protein content in strawberry plants. Plants Sci. 2004; 3: 739-44.

9. Haluskova L, Valentovicova K, Huttova J, Mistrik I, Tamas L. Effect of abiotic stresses on glutathione peroxidase and glutathione S-transferase activity in barley root tips. Plant Phys Biochem. 2009; 47(11-12): 1069-74.

10. Klimenko SV. Theoretical and practical aspects of analytical and synthetic selection of nonconventional fruit plants in the light of N. I. Vavilov's doctrine. In: Introduction of plants in beginning of the XXI century: achievements and prospects. To the 120 anniversary from the date of N. I. Vavilov's birth. Kyiv: Fitosociocentre; 2007: 31-41.

11. Klimenko S, Brinza J, Grygorieva O. Nontraditional fruits and berry plants in the Register of sorts of plants of Ukraine. In: Bezpecnost a kvalita potravin. Nitra; 2010: 244-7.

12. Kolupaev YE, Karpec YE. Formation of plant adaptive responses on abiotic stresses. Kiev: Osnova; 2010.

13. Kucherenko VP, Kapustyan AV. Peroxidase and winter hardiness of plant. Kyiv: Sociocentre; 2004.

14. Lagrimini L, Brabford L, Rothstein S. Tissue specificity of tobacco peroxidase isozymes and their induction by wounding and tobacco mosaic virus infection. The Plant Cell. 1990; 2: 7-18.
15. Lykholat YV, Rossikhina-Galich AS, Trokhaniak OS, Hrygoryuk IP. Operation of prooxidant-antioxidant system in leaves of the horse chestnut ordinary and chestnuts in the conditions of technogenic pollution and water scarcity. Naukovy dopovidi NUBIP. 2015; 5(54): 1-12. http:// http://nd.nubip.edu.ua/2015_5/7. pdf: 1-9.

16. Mezhenskij VN. Collection of alternative fruit crops in Artemovsk's research centre of UAAS Gardening institute. Industrial Botany. 2005; Issue 5: 109-13.

17. Minnibaeva FV. Production and activity extracellular peroxidase in plant tissue under stress. Physiology of Plant. 2003; 50. Issue 3: 459-65.

18. Mitteler R. Oxidative Stress, Antioxidants, and Stress Tolerance. Trends Sci. 2002; 7: 405-9. Petrova V. P. Biochemistry of wild-growing fruit and berry plants. Kyiv: Vyscha Shkola; 1986.

19. Petrova V. P. Biochemistry of wild-growing fruit and berry plants. Kyiv: Vyscha Shkola; 1986.

20. Petrovskaya-Baranova TP. Physiology of adaptation and plant introduction. Moscow: Nauka; 1983.

21. Popkova LL. Isofermental peroxidase spectrum of some Crimea orchid as criterion of stability. Biol Bull. 2006; 10(2): 59-61.

22. Rossihina GS, Lykholat YV, Kurpita LV. The activity of enzymes-detoksikator of reactive oxygen species of getnotify herbs with complex action of toxicants. Visn Lviv Univ SerBiol. 2011; 56: 239-44.

23. Rygetti P. Isoelectric focusing: the theory, methods and application. Moscow: Mir; 1986.

24. Sadvakasova GG, Kunaeva RM. Some physical, chemical and physiological properties of plant peroxidase. Physiol and Biochem of Cult Plants. 1987; 9(2): 107-19.

25. Shupranova L, Bylchuk V, Boguslavskaya L, Rossihina A, Vinnichenko A. Modern methods of the biochemical plant analysis. Dnepropetrovsk: DNU; 2011. 
26. Song YL, Feng ZB, Cheng YX, Gao JM. Chemical components of Chaenomeles speciosa (Sweet) Nakai. Acta Bot Boreali Occident Sin. 2007; 27: 831-3.

27. Sorokopudov VN, et al. Perfection of alternative garden culture assortment in Russia fFundamental investigations. 2013; 11(1): 115-21.

28. Verslues Paul E, Agarwal Manu, KatiyarAgarwal Surekha, Zhu Jianhua, Zhu JianKang. Methods and concepts in quantifying resistance to drought, salt and freezing, abiotic stresses that affect plant water status. The Plant Journal. 2006; 45: 523-39.

29. Vinnichenko AM, Bilchuk VS, Lykholat YV, Rossihina-Galicha AS, Shupranova LV. Practicum on physiology and biochemistry of plants. Dnepropetrovsk: Serednyak T.K. 2014.

30. Yang YB, Yang Y, Li X, et al: Studies on the chemical constituents of Chaenomeles speciosa. J Chin Med Mater. 2009; 32: 1388-90.

31. Yermakov OY. Modern state and features of industrial gardening development in Ukraine. Gardening. 1999; 49: 194-204.

32. Zaytceva IO, Dolgova LG. Physiological and biochemical bases of wood plant introduction in Steppe Prydneprovye. Dnepropetrovsk: DNU; 2011.
Yuriy Prisedsky, Anatoliy Kabar, Yuriy Lykholat, Nadezhda Martynova, Larysa Shupranova

\section{JAPONINIO SVARAINIO VEGETACINIŲ ORGANŲ AKTYVUMAS IR PEROKSIDAZĖS IZOFERMENTŲ SUDĖTIS STEPIŲ ZONOS SĄLYGOMIS}

\section{Santrauka}

Peroksidazès kompleksas atspindi prisitaikymo procesus, vykstančius augaluose veikiant aplinkai. Šiame darbe buvo tiriama japoninio svarainio (Chaenomeles Lindl.) vegetacinių organų bendra veiklos dinamika ir peroksidazès izofermento sudètis. Ištirtos keturios svarainių rūšys, introdukuotos ị Ukrainos stepių zoną: Ch. japonica (Thunb.) Lindl., Ch. speciosa (Sweet) Nak., Ch. cathayensis (Hemsl.) Schneid., Ch. $\times$ superba (Frahm) Red. Nustatyta, kad šių rūšiu fermentinis aktyvumas priklauso nuo sezoninio vystymosi fazių ir atsako į hidroterminį stresą. Didžiausias fermento aktyvumas užfiksuotas Ch. speciosa ir Ch. cathayensis lapuose intensyvaus augimo ir žydejjimo laikotarpiu, vèliau jis staigiai mažèjo iki vasaros vidurio ir palaipsniui mažèjo fiziologinio poilsio fazeje. Aukštesnis peroksidazès aktyvumas buvo būdingas $C h$. japonica ir Ch. $\times$ superba rūšims vegetacinio laikotarpio viduryje, ir ji galima laikyti prisitaikymo procesų rodikliu nepalankaus hidroterminio režimo sąlygomis. Peroksidazės kiekybinès sudèties pokyčio dinamika, tiriant izofermentų elektroforetini spektrą, buvo panaši ị bendrą jų aktyvumą. Tyrimo duomenimis, Ch. japonica ir Ch. $\times$ superba yra patvariausios regiono sąlygomis.

Raktažodžiai: japoninis svarainis, peroksidazé, prisitaikymas, stabilumas 